\title{
ANALISIS KESALAHAN BERBAHASA DALAM PENULISAN SURAT UNDANGAN ORGANISASI HMKM
}

\author{
Nur Kholijah \\ Pendidikan Bahasa dan Sastra Indonesia \\ Fakultas Keguruan dan Ilmu Pendidikan \\ Universitas Riau \\ nkholijah7@gmail.com
}

\begin{abstract}
Abstrak
Surat adalah sarana komunikasi tertulis yang digunakan untuk menyampaikan informasi darisatu pihak ke pihak lain. Dalam penulisan surat undangan yang dilakukan oleh organisasi kemahasiswaan Himpunan Mahasiswa Kecamatan Moro terdapat kesalahan berbahasa. Kesalahan berbahasa tersebut dapat digolongkan kesalahan dari sudut ejaan dan kesalahan dari sudut tata bahasa. Kesalahan dari sudut ejaan, misalnya kesalahan dalam penulisan di kepala surat, tanggal surat, nomor, lampiran, hal, dan isi surat. Kesalahan dari sudut tata bahasa ada dua, yaitu pemakaian kata ganti dalam alinea penutup isi surat dan masih terdapat kalimat fragmentaris.
\end{abstract}

Kata-kata Kunci: kesalahan berbahasa, surat undangan, organisasi mahasiswa.

\section{Pendahuluan}

Manusia sebagai mahluk sosial dalam kehidupan sehari-hari tentu memerlukan komunikasi dengan manusia yang lain. Alat/sarana yang digunakan untuk berkomunikasi verbal adalah bahasa. Dapat dikatakan bahwa bahasa memiliki peranan yang sangat penting dalam kehidupan manusia. Pentingnya bahasa itu ternyata mencakup segala aspek kehidupan manusia. Segala sesuatu yang dirasakan, dialami, dihayati, dan dipikirkan oleh manusia hanya dapat diketahui manusia lain jika telah diungkapkan dengan bahasa.

Melalui bahasa, manusia berkomunikasi dengan manusia lain untuk berbagai keperluan dalam kehidupannya, baik secara lisan maupun tulis dan secara langsung maupun tidak langsung. Salah satu alat komunikasi tertulis yang digunakan dalam berkomunikasi adalah surat. Surat selain sebagai sarana komunikasi, juga mempunyai berbagai fungsi lain. Fungsi-fungsi tersebut adalah 1) sebagai alat untuk menyampaikan pemberitahuan, permintaan atau permohonan, buah pikiran atau gagasan; 2) alat bukti tertulis; 3) alat untuk mengingat; 4) bukti historis, dan 5) pedoman kerja (Sudarsa dkk, 1991: 3) 
.Dilihat dari segi bentuk, isi, dan bahasanya, menurut Sudarsa (1991:3) surat dapat digolongkan atas tiga jenis, yaitu 1) surat pribadi, 2) surat dinas, dan 3) surat niaga. Dalam surat dinas terkandung informasi-informasi tertentu yang dapat berupa perintah, pemberitahuan, undangan, tugas, permintaan, teguran, dan lain-lain. Untuk itu, surat hendaknya ditulis menggunakan bahasa yang sangkil dan mangkus, bahasa yang baik dan benar sesuai dengan kaidah bahasa Indonesia yang berlaku. Kesalahan-kesalahan yang sering terjadi dalam penulisan surat dinas adalah penggunaan bahasa yang tidak baku.

Demikian juga dalam surat-menyurat yang dilakukan oleh organisasi kemahasiswaan HMKM masih terdapat kesalahan-kesalahan dari sudut bahasa yang digunakan. Kesalahan secara garis besar dapat dipilah menjadi dua, yaitu kesalahan dari sudut ejaan dan sudut tata bahasa. Kedua jenis kesalahan ini untuk pembetulannya sudah ada parameter/aturannya, yaitu untuk ejaan patokannya adalah Pedoman Umum Ejaan Bahasa yang Disempurnakan (1988) dan untuk tata bahasa pedomannya adalah Tata Bahasa Baku Bahasa Indonesia (1988).

\section{Metode Penelitian.}

Metode yang digunakan dalam penelitian ini adalah metode deskriptif analitis. Arikunto (2010: 3) mengatakan metode deskriptif merupakan penelitian yang benar-benar hanya memaparkan apa yang terdapat atau terjadi dalam sebuah kancah lapangan, atau wilayah tertentu. Dalam penelitian ini penulis menggunakan metode deskriptif analitis dengan tujuan agar dapat mendeskripsikan kesalahan berbahasa dalam penulisan surat undangan organisasi.

Sumber data dalam penelitian ini adalah surat undangan organisasi himpunan mahasiswa kecamatan Moro. Teknik pengumpulan data yang penulis gunakan dalam penelitian ini adalah teknik dokumentasi. Menurut Arikunto (2010: 274), Teknik dokumentasi adalah teknik yang digunakan untuk mencari data, hal-hal variabel yang berupa catatan, buku-buku, majalah, surat kabar, majalah, prasasti, notulen rapat dan lain-lain.

Dokumen yang digunakan dalam penelitian ini adalah surat undangan yang dikirimkan oleh organisasi himpunan mahasiswa Kec.Moro. Adapun langkah kerja yang dilakukan penulis adalah membaca surat undangan yang diarsipkan oleh himpunan mahasiswa Kec. Moro dari bulan Maret - Juni 2020 dan kemudian membuat catatan yang berkaitan kesalahan berbahasa dalam surat undangan yang dikirimkan oleh organisasi himpunan mahasiswa Kec.Moro.

Berdasarkan metode penelitian yang peneliti gunakan dan objek penelitian berupa surat yang dikirimkan oleh organisasi himpunan mahasiswa Kec.Moro. adapun cara menganalisis data yaitu mengidentifikasi, mengklasifikasi, menganalisis, membahas hasil analisis, dan simpulan.

\section{Hasil dan Pembahasan}




\section{Kesalahan Berbahasa dalam Penulisan Surat Undangan Organisasi Kemahasiswaan}

Untuk memperbaiki segala sesuatu yang salah, harus diketahui terlebih dahulu letak kesalahannya dengan tepat. Demikian juga untuk menganalisis kesalahan berbahasa dalam penulisan surat undangan organisasi kemahasiswaan HMKM perlu diketahui terlebih dahulu letak kesalahannya dengan tepat. Yang dimaksud dengan kesalahan adalah segala sesuatu yang menyimpang dari aturan, norma, atau prosedur baku yang berlaku.

Kesalahan dalam pemakaian berbahasa/berbahasa secara garis besar dapat dikelompokkan menjadi dua, yaitu kesalahan dalam bidang ejaan dan kesalahan dalam bidang tata bahasa. Acuan/parameter/tolak ukur untuk menganalisis kesalahan ejaan dalam bahasa Indonesia sudah cukup jelas, yaitu Pedoman Umum Ejaan Bahasa Indonesia yang Disempurnakan (EyD). Jadi, segala macam penulisan terkait dengan segi ortografis/tata tulis dikatakan salah apabila tidak sesuai dengan aturan-aturan atau ketentuan-ketentuan yang terdapat dalam Pedoman Umum Ejaan Bahasa Indonesia yang Disempurnakan (EyD).

Kesalahan yang berkait dengan tata bahasa, dalam bahasa Indonesia juga sudah jelas parameter/tolak ukurnya. Parameter/pedoman/tolak ukur berbahasa kaitannya dengan tata bahasa dalam bahasa Indonesia adalah aturan-aturan/kaidah-kaidah yang termaktub dalam Tata Bahasa Baku Bahasa Indonesia. Jadi, pemakaian bahasa dianggap salah/tidak tepat dari sudut tata bahasa apabila penyusunannya tidak sesuai dengan aturan-aturan/kaidah-kaidah yang termasuk dalam Tata Bahasa Baku Bahasa Indonesia.

\section{Kesalahan Ejaan/Tata Tulis}

Kesalahan dari segi tata tulis/ejaan yang masih terdapat dalam surat undangan yang disusun oleh organisasi himpunan mahasiswa Kec. Moro meliputi: kesalahan penulisan pada kepala surat, tanggal surat, lampiran, hal/perihal, alamat surat, dan isi surat.

Kesalahan Berbahasa dalam Penulisan Surat Undangan Organisasi Kemahasiswaan

Untuk memperbaiki segala sesuatu yang salah, harus diketahui terlebih dahulu letak kesalahannya dengan tepat. Demikian juga untuk menganalisis kesalahan berbahasa dalam penulisan surat undangan organisasi kemahasiswaan di organisasi HMKM perlu diketahui terlebih dahulu letak kesalahannya. Yang dimaksud dengan kesalahan adalah segala sesuatu yang menyimpang dari aturan, norma, atau prosedur baku yang berlaku.

Kesalahan berbahasa adalah penggunaan bahasa yang menyimpang dari kaidah bahasa yang berlaku dalam bahasa itu. Sementara itu kekeliruan adalah penggunaan bahasa yang menyimpang dari kaidah bahasa yang berlaku dalam bahasa itu namun tidak dipandang sebagai suatu pelanggaran berbahasa. Kesalahan dalam pemakaian berbahasa/berbahasa secara garis 
besar dapat dikelompokkan menjadi dua, yaitu kesalahan dalam bidang ejaan dan kesalahan dalam bidang tata bahasa. Ejaan biasanya memiliki tiga aspek yaitu:

1. Aspek fonologis, yang menyangkut penggambaran fonem dengan huruf dan penyusunan abjad.

2. Aspek morfologis, yang menyangkut penggambaran satuan-satuan morfemis.

3. Aspek sintaksis, yang menyangkut penanda ujaran berupa tanda baca.

Kesalahan dari segi tata tulis/ejaan yang masih terdapat dalam surat undangan yang disusun oleh organisasi kemahasiswaan HMKM meliputi: kesalahan penulisan pada kepala surat, tanggal surat, lampiran, hal/perihal, alamat surat, dan isi surat.

1. Kesalahan Penulisan pada Kepala Surat Dalam penulisan kepala surat/kop surat masih terdapat beberapa kesalahan, yaitu 1) penulisan kata Jalan disingkat menjadi JL. atau J1. bahkan ada yang langsung nama jalannya. Sesuai EYD harusnya ditulis lengkap dan kalau mau disingkat Jln. Bukan JL. atau Jl.

2. Penulisan nama tidak seragam, ada yang menuliskan Bpk. Camat, KA. Camat, Bapak Camat Moro.

3. Penulisan kata telepon menjadi telpon dan ada yang disingkat menjadi Telp. atau Tlpn. Sesuai aturan harusnya ditulis lengkap Telepon.

4. Kesalahan Penulisan pada tanggal surat. kesalahan-kesalahan yang terdapat dalam penulisan tanggal surat sebagai berikut. Penulisan tanggal surat didahului nama tempat, contoh: a) Moro, 6 Maret 2020, b) Moro, 23 April 2020, c) Moro, 5 Mei 2020, dan d) Moro, 23 Juni 2020. Seharusnya, sebelum tanggal tidak dicantumkan nama kota karena nama kota itu sudah tercantum pada kepala surat. Penulisan angka tanggal yang terdiri atas satu angka di depannya ditambah angka nol, contoh: 04 Juni 2020. Penambahan angka nol tersebut tidak ada gunanya sehingga lebih baik dan lebih efektif tidak dituliskan.

5. Kesalahan Penulisan di Lampiran Berkaitan dengan penulisan lampiran kesalahan yang terjadi adalah penulisan kata lampiran ditulis Lamp tanpa tanda baca apa pun. Padahal yang betul ditulis lengkap atau disingkat Lamp. (ada tanda titiknya). Selain itu, terdapat tulisan Lamp tetapi tidak ada sesuatu yang dilampirkan bersama surat, contoh: Lamp : -. kalau tidak ada sesuatu yang dilampirkan bersama surat jangan ditulis Lampiran atau Lamp.

6. Kesalahan Penulisan di Hal/Perihal Terdapat penulisan Hal/Perihal yang isinya ditulis dengan diberi garis bawah, contoh: Hal: Undangan. Yang benar, untuk Hal/Perihal berkaitan dengan isi surat tidak perlu diberi garis bawah. 
7. Kesalahan penulisan alamat surat, terdapat beberapa kesalahan, yaitu: 1) diawali dengan preposisi kepada. Seharusnya tidak perlu dituliskan preposisi Kepada karena dalam surat tersebut tidak didahului dengan preposisi Dari. Selain itu, sudah seharusnya surat-surat itu dikepadakan sehingga akan lebih hemat/tidak mubazir kalau langsung ditulis Yth. diikuti nama jabatan atau orang yang dituju. 2) Alamat yang dituju tidak ditulis secara lengkap.

Contoh: Yth. Drs. Mujid Farihul Amin, M.Pd.

Di Tempat

Kepada Yth. Drs. Mujid Farihul A,M.Pd.

Di tempat

Sesuai dengan aturan penulisan alamat surat, harusnya ditulis sebagai berikut.

Yth. Drs. M. Amin, M.Pd.

Moro atau

Yth. Bpk. Camat Moro.

8. Kesalahan Penulisan di Isi Surat

a. Alinea Pembuka dan Isi Dalam surat undangan.

alinea pembuka dan isi sering dijadikan satu. Kesalahan penulisan yang terdapat dalam alinea ini sebagai berikut :

Sehubungan dengan diselenggarakannya acara Peringatan hari sumpah pemuda yang dilaksanakan oleh Volunteer Group dan Maritime Study Group Fakulta pada:

Sehubungan dengan adanya talkshow yang akan dilaksanakan HMKM, kami akan mengadakan rapat untuk membahas lebih lanjut hasil diskusi saat talkshow, yang akan dilakasanakan pada...

Sehubungan akan dilaksanakan kegiatan Achievement Motivation Training (AMT) yang akan diselenggarakan pada ...

Sehubungan dengan diselenggarakannya Musyawarah Besar (MUBES) yang bertema "LEADERSHIP" oleh HMKM pada ...

Waktu: 08.00 s/d selesai dan Waktu: 08.30 s/d selesai. 
Kesalahan penulisan yang terdapat pada data di atas adalah kesalahan penulisan kosakata yang berasal dari bahasa asing. Kosakata yang berasal dari bahasa asing apabila terdapat dalam tulisan yang konteksnya bahasa Indonesia harusnya ditulis dengan huruf miring. Jadi kata Volunteer Group, Maritime Study, talkshow, dan Achievement Motivation Training harusnya ditulis dengan huruf miring menjadi Volunteer Group, Maritime Study, roadshow, Achievement Movation Training. Untuk data terakhir, kesalahannya pada penulisan s/d harusnya tidak ditulis dengan garis miring tetapi dengan tanda titik s.d. atau ditulis dengan lengkap sampai dengan dan bisa juga diganti dengan tanda hubung $(-)$.

b. Alinea Penutup

Kesalahan dari segi penulisan dalam alinea penutup dapat dilihat pada data berikut :

(a) Atas perhatian dan kerjasamanya kami ucapkan terima kasih.

(b) Atas perhatian dan kerjasama Bapak, kami ucapkan terima kasih.

(c) Atas perhatian Saudara/i kami sampaikan terimakasih.

Pada data a) dan b) penulisan kata kerjasamanya dan kerjasama tidak tepat, harusnya yang benar adalah kerja sama Bapak dan kerja sama. Pada data c), kesalahan terdapat dalam penulisan Saudara/i dan terimakasih yang benar adalah Bapak dan terima kasih.

\section{Kesalahan dari Segi Tata Bahasa}

(1) Pemakaian Kata Ganti

Dalam alinea penutup, sering terdapat kesalahan pemakaian kata ganti -nya. Kata ganti nya merupakan kata ganti orang/pronomina persona yang merujuk kepada orang ketiga bukan kata ganti orang kedua, contoh: Atas perhatiannya, kami ucapkan terima kasih. Padahal dalam surat-menyurat tersebut (surat undangan) yang diajak berkomunikasi adalah orang kedua. Jadi, pronomina -nya dalam kata perhatiannya tidak merujuk kepada orang yang diajak berkomunikasi tetapi merujuk kepada orang lain di luar komunikan dan komunikator. Untuk itu, alinea penutup tersebut harus dibetulkan sehingga berbunyi: Atas perhatian Bapak/Ibu/Saudara, kami ucapkan terima kasih.

(2) Kalimat Fragmentaris Kalimat fragmentaris adalah kalimat yang belum selesai. Kalimat terjadi antara lain karena adannya keinginan penulis menggunakan gagasan dalam beberapa kalimat tanpa menyadari kesatuan gagasan yang diungkapkan. Tentu saja, 
apabila terdapat kalimat seperti ini dalam sebuah surat akan membingungkan pemahaman pembaca terhadap isi informasi atau pesan yang akan disampaikan.

\section{Kesimpulan}

Berdasarkan penelitian dan pembahasan kesalahan berbahasa yang telah peneliti lakukan pada surat undangan yang disusun oleh organisasi kemahasiswaan HMKM dapat disimpulkan bahwa terdapat kesalahan berbahasa dalam penulisan surat undangan tersebut. Kesalahan berbahasa dapat dilihat dari dua sudut, yaitu kesalahan dari ejaan dan kesalahan dari tata bahasa. Kesalahan sudut ejaan, misalnya kesalahan dalam penulisan di kepala surat, tanggal surat, nomor, lampiran, hal, da isi surat.

Kesalahan dari sudut ejaan disebabkan penulisan pada bagian surat yang tidak sesuai dengan aturan yang ada dalam Pedoman Umum Ejaan Bahasa Indonesia yang Disempurnakan (EYD). Kesalahan penulisan surat undangan dari sudut tata bahasa karena penyusunan kalimat yang tidak sesuai dengan aturan atau kaidah yang ada dalam Tata Bahasa Baku Bahasa Indonesia.

\section{Daftar Pustaka}

Alwi, Hasan dkk. (ed). 2003. Tata Bahasa Baku Bahasa Indonesia.

Jakarta: Balai Pustaka.

Anam, Samsul. 2012. Analisis Kesalahan EyD dalam Surat Undangan Dinas

di Kantor Kecamatan Peninjauan Kabupaten Oku. dimuat dalam Lentera Pendidikan Volume V Nomor 3 Oktober 2012.

Arikunto, Suharsimi. 2010. Prosedur Penelitian: Suatu Pendekatan Praktik. Jakarta: Rineka Cipta.

Pusat Pembinaan dan Pengembangan Bahasa. 1988. Pedoman Umum

Ejaan Bahasa Indonesia yang Disempurnakan. Jakarta: PN Balai Pustaka.

Sudarsa, Caca. 1989. Ancangan Mutakhir Penulisan Surat Resmi Indonesia.

Bahan Penyuluhan Surat-Menyurat di Pusdiklat

Departemen Pendidikan dan Kebudayaan. Jakarta: Pusat Bahasa.

Sudarsa, Caca dkk. 1991. Seri Penyuluhan 2: Surat-Menyurat dalam Bahasa Indonesia. 
Jakarta: Pusat Pembinaan dan Pengembagan Bahasa, Departemen Pendidikan dan Kebudayaan.

Sumantri, Maman dkk. 1985. Pedoman Surat-Menyurat.

Jakarta: Pusat Bahasa.

Sudaryono. 1988. Surat-menyurat dalam Bahasa Indonesia.

Bandung: Angkasa. 